\title{
Catchment Water Balance Modelling in Australia 1960-2004
}

\author{
W. Boughton \\ Honorary Senior Fellow, Griffith University, Brisbane, Australia
}

\author{
Postal address: 11 Preston Place, Brookfield, Queensland 4069, Australia \\ (please use above address for all correspondence) \\ Telephone: $\quad+61-7-3374-3718$ \\ Email: $\quad$ wboughto@bigpond.net.au
}

\begin{abstract}
Computer simulation of the water balance of catchments for estimating runoff from rainfall began in Australia about four decades ago. It is now a mature technology with numerous models in use for design of water supply systems, flood estimation, management of water resources for allocation and use, management of stormwater and wastewater in urban areas, and management of aquatic ecosystems. Only two models developed in the USA (Sacramento and Curve Number) are in common use in Australia, while several models developed in Australia are in common use. A majority of the models developed in Australia came from higher degree projects in universities. There are several instances of a model developed in one higher degree project forming the basis of a model in a later project. A significant feature of Australian work is the development of many simple models compared to the relative complexity of models developed elsewhere. Several substantial studies have attempted to establish procedures for use of water balance models on ungauged catchments with little success. Almost all use of water balance models in Australia is where streamflow data are available for calibration of model parameters.
\end{abstract}

Keywords: Hydrological modelling, Rainfall-runoff models, water balance

\section{Introduction}

Computer modelling of the water balance of catchments is one of the major paradigms of modern catchment hydrology. It began in the early 1960s with the Stanford Watershed Model. At the time of writing, the models based on explicit catchment water balance modelling are numbered in the hundreds and new models are still being presented. The success of the paradigm in relating runoff to rainfall is due to the constraint imposed by the need to account for all water entering, leaving and being stored in a catchment. This adaptation of the principle of Conservation of Mass constrains the potential for error. The fact that so many water balance models with different structures give results of similar accuracy is evidence that the underlying principle is responsible for the success.

The start in 1960 was due to the emerging availability of computing resources that are necessary for the detailed calculations of catchment water balance. The subsequent developments of the field have paralleled the developments in computing capacity and availability.

In this paper, water balance modelling refers to the continuous simulation of catchment water balance through dry periods as well as wet. Event based modelling, used mainly for flood analysis or estimation, involves assumptions of initial and continuing losses from rainfall in order that a water balance is achieved through a single storm. This paper deals with the models that calculate a continuous water balance without need for assumptions to deal with particular storm events. 
Most of the books and major reviews of the topic have been prepared in the USA, and these give only a little attention to Australian work. There are substantial differences in approach between the USA and Australia that are not evident in the USA publications. The dominant interest in water balance modelling in Australia is in the estimation of water yield whereas in the USA it is in flood estimation. An outstanding feature of water balance modelling in Australia has been the development of numerous simple models whereas USA models tend to be more complex - contrast the complexity of the Sacramento and Stanford Watershed Models (each with more than 20 parameters) with the simplicity of the SIMHYD (7 parameters) and AWBM (3 parameters) models.

Another feature of Australian work that is not evident in reviews to date is the large proportion of model development that has been made in higher degree projects in universities. Although development of rainfall-runoff models in higher degree projects in other countries is evident in the literature, the percentage of Australian models developed in this way is very high.

This review covers the main developments in water balance modelling in Australia and gives perspective to the current situation and possible future trends. Section 2 describes earlier reviews with emphasis on Australian work and a lesser coverage of other significant reviews. Section 3 describes the main models that have led to the current level of modeling technology, and mentions some of the major modeling studies in Australia. Structures of three models are given as examples in Section 4. Several studies have used sensitivity analysis to reduce the number of variable parameters in models and the main studies are described in Section 5. The use of water balance modeling for flood estimation is described in Section 6, and the studies aimed at the use of water balance models for estimation of water yield of ungauged catchments are reviewed in Section 7. The current situation and possible future trends are discussed in Section 8, with some concluding comments in Section 9.

\section{Prior Reviews}

The reviews by Ayers (1962) and Bell (1966) of methods for estimating catchment water yield were made just at the start of computer water balance modelling. They make brief mention of the Stanford Watershed Model, but mainly cover the methods and approaches used before computer modelling of catchment water balance began.

The USDA Curve Number method of estimating runoff from rainfall began as a manual calculation event-based method (Mockus 1949, Ogrosky and Mockus 1964) but it was eventually changed to a continuous moisture accounting model to determine daily runoff from daily rainfall (Williams and LaSeur 1976). It has probably been used more throughout the world than any other single rainfallrunoff method - see reviews by Rallison (1980), Boughton (1989) and Ponce and Hawkins (1996).

The first review of computer models of catchment water balance in Australia was by Pattison and McMahon (1973). This review was made on behalf of the National Committee on Hydrology of the Institution of Engineers, Australia (the predecessor of the current National Committee on Water Engineering). There were 5 models covered in the review, and the text reflects the attitudes about catchment modelling at that early stage.

In 1975, the Australian Academy of Science sponsored a National Symposium on "Prediction in Catchment Hydrology” (see Chapman and Dunin, eds. 1975). The 21 papers presented in this symposium were mainly review papers covering individual physical processes (interception, 
infiltration, etc.), data for models, trends in catchment modelling, and some other aspects. The extensive sets of references in this publication, particularly with the attention given to Australian work, make this a valuable publication.

In the same year, Fleming (1975) gave a description of 12 continuous simulation models (only one from Australia). The majority of the models were from the USA. This publication gives more attention to the models than the Academy of Science 1975 symposium. By this time, the World Meteorological Organization had taken an interest in catchment water balance models for flood forecasting purposes, and presented a comparison of several models (WMO 1975).

Mein (1977) presented a state-of-the-art review of catchment water balance models. This review contains little detail of the structure of the various models but gives attention to operational aspects that had become of importance by 1977. These include methods for the evaluation of model parameters, comparisons between process and black-box models, resources required for modelling and the results that had been obtained from models.

The American Society of Agricultural Engineers produced a monograph (Haan et al 1982) that is a major text on hydrological modelling of small catchments. In a manner similar to the Academy of Science symposium, this 533 page publication covers most aspects of computer modelling of the water balance of catchments, such as precipitation, evaporation, etc. The final chapter contains a summary of 75 models of which 20 are catchment water balance models. This summary shows how water balance modelling had developed in the 20 years since the introduction of the Stanford Watershed Model.

A major review of Australian models was presented by Boughton (1988) as part of a Bicentennial Review of Australian Hydrology by the National Committee on Water Engineering of the Institution of Engineers, Australia. The 84 references in this review cover most of the water balance modelling work in Australia up to 1987. Many of the early Australian models are briefly described.

The review by Croke and Jakeman (2001) gives a very broad description of Australian hydrology and the role of catchment models in elucidating hydrological processes in different regions. By the start of the new millennium, the interest in catchment modelling had shifted away from the structure and performance of different models and towards such aspects as factors affecting model performance, the ability of models to simulate the hydrological effects of change in land use and change in climate, and incorporating remotely sensed data into catchment models.

About the start of the new millennium, the Cooperative Research Centre for Catchment Hydrology began the preparation of a Modelling Toolkit to assist the parties who formed the CRC with their catchment modelling work. At the start of the project, a survey was made (Marston et al 2002) to determine the nature and range of hydrologic models in use, and to determine the modelling needs of the managers of land and water resources. There were 36 models cited in the returns to the survey but this includes a range of different types of models, and not all were water balance models. Only 14 models were used by more than one respondent. A significant feature of the returns was that there was no expressed need for improvements to current water balance models but there was much need to couple the modelling of water quality variables (sediment, salt, nutrients) to the modelling of water runoff. This survey is also unusual in that the coverage was of practitioners and practical use of models rather than the usual collation of research/academic publications.

The above are the main reviews of Australian work. Most of the other reviews and collations of information give emphasis to USA work, but they also provide some perspective to contemporary 
Australian work. The publications by Todini (1988), Wheater et al (1993), Singh (1995), Singh and Frevert (2002), and Singh and Woolhiser (2002) give significant coverage of the topic.

\section{Australian Water Balance Models}

The following is not an exhaustive review of Australian water balance models. Many models are mentioned once in the literature and never appear again. The following models are those that have had some significant use and have been part of the development of Australian water balance modelling. The order of presentation is approximately the order of development.

\section{\{Note to Editor - locate Table 1 here}

\subsection{Boughton Model}

The Boughton model was developed as a Master of Engineering thesis project at the University of New South Wales (Boughton 1964). It was the first computer simulation model of catchment water balance developed in Australia. Descriptions of the model are given in Boughton (1968) and Pattison and McMahon (1973). The review by Boughton (1988) covers most of the studies of the model and the work in which it was used up to 1987 (by which time the use of the model was virtually finished).

The original model did not contain a baseflow runoff component but that was added in later versions. Two aspects of the model are noteworthy. First, the model used only daily rainfall data that was widely available in Australia; hence the model could be used at any location with a period of streamflow record for calibration. This made the model more attractive than models that needed pluviometer data. Second, the model was very simple and easy to understand and use, and the computer program was freely available. The simplicity of the model encouraged other developments by engendering an "I can do that!" attitude (see also 3.4 SFB Model).

\subsection{The Australian Representative Basins Model}

The Australian Representative Basins Model evolved over a number of years from the late 1960s to the mid-1970s in CSIRO's Division of Land Use Research (Chapman 1968). The model is described by Black and Aitken (1977). The model was developed as part of the Australian Representative Basins Programme (Australian Water Resources Council 1969) and was intended to be the main analytical tool for study of rainfall and runoff data that was collected during that programme. Details of the history and purpose of the model and the programme are given in Fleming (1971) and by the Council (Australian Water Resources Council 1973). The model time step is as short as 6 minutes during rain and normally one day in periods between storms. The version of the model described by Black and Aitken (1977) has 19 parameters.

The model was eventually incorporated into the RAFTS-XP commercial package (Goyen et al 1991, Phillips and Boon 1999), and this has provided application of the model after its initial purpose had lapsed.

\subsection{Monash Model}

The Monash Model was developed at Monash University as a $\mathrm{PhD}$ project by Porter (1972). The model is described by Porter and McMahon (1971). The model contains a runoff routing procedure, 
similar to the RORB flood hydrograph model, and a catchment water balance procedure. It can be operated on either a daily or hourly time step (see also 3.6 SIMHYD).

\subsection{SFB Model}

This model was developed from the Boughton model (see 3.1 above) with many of the original nonsensitive parameters given fixed values (Boughton 1984). The letters in the title refer to the 3 parameters in the model - $\mathrm{S}$ for the surface storage parameter, $\mathrm{F}$ for the percolation parameter, and $\mathrm{B}$ for the baseflow discharge parameter. The model was extensively used because of the small number of parameters and its overall simplicity. Nathan and McMahon (1990a, b, c) used the model in a study of 184 catchments, 1 to $250 \mathrm{~km}^{2}$ in area, in New South Wales and Victoria. The study was funded by the Australian Water Research Advisory Council as Project 85/105, aimed at the estimation of runoff from ungauged catchments. The SFB was eventually replaced, mainly by the AWBM (see section 3.9), and is little used at the time of writing.

\subsection{Sacramento Model (NSW-RFS)}

The Sacramento model was developed in the USA and originally used for flood forecasting on the Sacramento River in California, hence it is known as the Sacramento model in Australia. In the USA, it is known as the National Weather Service River Forecast System. The main references are Burnash et al (1973) and Burnash (1975). In 1984, the Australian Water Resources Council sponsored a visit to Australia by one of the model developers (Burnash). The training programs and documentation of the model that became available from this visit were the original stimulants to its use. Although this model was not an Australian development, it is used as the main water balance component in the Integrated Quantity and Quality Model (IQQM) that is used extensively in the eastern States of Australia (Simons et al 1996).

\subsection{SIMHYD (MODHYDROLOG)}

The computer program for the daily version of the Monash model was named HYDROLOG (Porter and McMahon 1976). The baseflow processes in HYDROLOG were modified to produce the MODHYDROLOG model in a PhD project by Chiew (Chiew 1990, Chiew and McMahon 1990, 1991). This model had 17 parameters. A sensitivity analysis by Chiew and McMahon $(1993,1994)$ showed that modelled streamflow was insensitive to many of the parameters. Eventually a simplified version with 7 parameters, SIMHYD, was developed (Chiew et al 2002a).

The MODHYDROLOG model was used in a study of 28 catchments spread among 6 States of Australia (Chiew and McMahon 1994). The SIMHYD model was used in a study of rainfall-runoff data from 331 Australian catchments undertaken for the National Land and Water Audit (Peel et al 2001), and the South East Queensland Environmental Management Support System (Chiew et al 2002b)

\subsection{TOPOG Model}

The TOPOG model (O’Loughlin 1986, O’Loughlin et al 1989) is a terrain analysis-based modelling package with more than 30 sub-programs. The model determines the areas of surface saturation in a catchment, and calculates runoff from rainfall as saturation overland flow runoff from the saturated areas. The model has its genesis in the mid-1980s at the Australian Centre for Catchment Hydrology (ACCH) in CSIRO Division of Water Resources, Canberra. The ACCH was eventually subsumed into the Cooperative Research Centre for Catchment Hydrology when that latter Centre 
began. The model is very demanding of input terrain data, and is intended for use on small catchments, generally $<1 \mathrm{~km}^{2}$. The original model was a steady-state model for determining saturated areas; however, a later version (TOPOG_Dynamic) can model the temporal water balance (see Silberstein et al 1999).

\section{8}

IHACRES Model

The IHACRES model was a joint development by the UK Institute of Hydrology and the Centre for Resource and Environmental Studies at the Australian National University (Jakeman et al 1990). The model operates on a daily time step and calculates quickflow and slowflow (i.e. surface runoff and baseflow) components of streamflow. The original version used a statistical approach to account for antecedent soil moisture conditions and evapotranspiration loss. Evans and Jakeman (1998) introduced a moisture accounting procedure to determine losses from rainfall and the generation of runoff, i.e. a change to a water balance model (see also Croke and Jakeman 2004). The model inputs temperature data in lieu of ET estimates and outputs calculated ET values as well as calculated runoff.

\subsection{AWBM Model}

The Australian Water Balance Model (AWBM) is based on saturation overland flow generation of runoff and has been developed from a theoretical analysis of the behaviour of elementary units of surface storage of catchment areas. It was developed in the early 1990s (Boughton 1993, Boughton and Carroll 1993) and is now one of the most widely used rainfall-runoff models in Australia. The main reference is Boughton (2004). A significant feature is the development of calibration procedures that are specific to the model and are based on the model structure, rather than the more common approach of trial and error testing of sets of parameter values. The model has a daily version for estimation of water yield and an hourly version for flood estimation. Recently the model was adapted for use on ungauged catchments, and calibrations of this version on 221 catchments in mainland Australia are presented in Boughton and Chiew (2003).

\subsection{MOSAZ Model}

In the early 1980s, Sukvanachaikul developed a 6-parameter monthly water balance model for semi-arid catchments as a PhD project at Monash University (Sukvanachaikul and Laurenson 1983). The model was later modified in another PhD project by Jayasuriya (1991), who changed the model to a daily time step and introduced a baseflow component of runoff (Jayasuriya et al 1991). Several versions of the modified model were tested with the number of parameters ranging from 2 to 6. The 2-parameter version was named MOSAZ for Modified Semi Arid Zone model. This version was later used in a study of 195 catchments in Victoria aimed at developing relationships that could be used to estimate monthly water yield on ungauged catchments (Nathan et al 1996).

\subsection{PERFECT Model}

PERFECT is a land management system model including components for estimating runoff, erosion and crop growth that was developed by the Queensland Dept. of Primary Industries (Littleboy et al 1993). The name is an acronym for Productivity Erosion Runoff Functions to Evaluate Conservation Techniques. The calculation of runoff has three options, two based on the USDA SCS Curve Number method and the other based on runoff functions from the Boughton model. The Curve Number methods are of continuous simulation form based on the work of Williams and LaSeur (1976). The PERFECT system has been modelled on the CREAMS system of the USDA, including 
the use of empirical relationships for estimating peak runoff rates from the daily runoff. The system is directed at applications involving agricultural scale catchments.

\subsection{AQUACYCLE}

AQUACYCLE is a daily urban water balance model that includes wastewater as well as runoff from rainfall. It accounts for the movement of water through the rainfall-drainage system and the supply-wastewater system as well as cross-links between the two. The model was developed as a $\mathrm{PhD}$ project at Monash University by Grace Mitchell (see Mitchell et al 1997). The paper by Mitchell et al (2003) gives a brief review of other urban models used in Australia.

\section{Model Structures}

Some of the models mentioned in the previous section are derivative, with a later model based on an earlier model; hence the structure of the first model persists in the latter model. Apart from such cases, there are substantial differences among model structures, with only a few common characteristics. Most are one-dimensional, using lumped input data that implies uniformity of water balance over the catchment. A majority are based on saturation overland flow generation of runoff. The modeled components of runoff vary from surface runoff only, to baseflow and interflow, to impervious area runoff, and (rarely) to subsurface stormflow.

Three models (MOSAZ, AWBM AND SIMHYD) have been selected as examples to illustrate model structure. All three have simple structures with two, three and seven variable parameters respectively. The structures are shown in Fig. 1.

\section{\{Note to Editor - locate Fig. 1 here\}}

MOSAZ is the simplest model. It is a saturation overland flow model based on a single water store that combines soil moisture and groundwater. Three components of runoff - surface runoff, interflow and baseflow - are simulated. Its major application to date has been to test relationships between the models two parameters (store capacity and a single discharge parameter for interflow and baseflow) and catchment characteristics for possible use of the model on ungauged catchments. Apart from that study, the model has been little used in practical applications.

The AWBM is the most widely used rainfall-runoff model in Australia. It is a saturation overland flow model that simulates surface runoff and baseflow. It is a semi-distributed model with three surface stores that allow for variation in the water balance and runoff generation over a catchment area. In its simplest form, it has three parameters - one defining a total surface capacity that is disaggregated using a fixed pattern into three capacities and partial areas, and two baseflow parameters. If the surface capacities and partial areas are calibrated individually there are seven parameters. The model is used on a daily time step for water yield studies and on an hourly time step for flood studies without any change to the basic structure.

SIMHYD is the most complex of the three but, with only seven parameters, it is still a simple model. It allows for both infiltration excess and saturation overland flow generation of runoff. It simulates surface runoff, interflow and baseflow. There is an interception store (top left of SIMHYD in Fig.1), a soil moisture store and a groundwater store. Although SIMHYD is not widely used, it has been the basis of some major hydrological studies (see Section 3.6). 
None of the models simulate deep drainage to regional groundwater because it is such a small component of the water balance and there are no measurements on which to base such a component. Snow covers a very small part of the Australian landscape and snow pack/melt models are only used by a few organizations. The models illustrated here are general purpose models aimed at general use in many locations.

\section{Parameter Reduction Studies}

In the 1970s, Johnston and Pilgrim (1976) made a major study of the Boughton model. The purpose was to calibrate the model, then relate the calibrated parameter values to catchment characteristics for later application to ungauged catchments. Instead, the study was a landmark in demonstrating that there were interrelationships among parameters such that many different sets of parameters produced almost identical calculations of runoff. This study had a major impact in prompting parameter reduction studies.

Several studies have used sensitivity analysis to identify parameters with little effect on output. The result of each study has been to reduce the number of variable parameters in a model by either assigning a constant value or else relating the value of a parameter to that of another, such that one value determines two or more of the original parameters.

The first such study was a reduction in the number of parameters in the Boughton model. There were several versions of this model with the number of parameters ranging from 9 to 13. By testing the sensitivity of the output to change in the value of each parameter, Boughton (1984) reduced the number of parameters to three in the SFB model. Nathan and McMahon (1990a) made a further study of the SFB structure but were unable to simplify the structure any further.

The MOSAZ model was developed from an earlier 6-parameter model. Jayasuriya et al (1991) made a detailed investigation of parameter interdependency and redundancy. They developed a 4parameter version, then a 3-parameter version, and finally a 2-parameter version. The steps in the parameter reduction and the results from each version of the model are given in Jayasuriya et al (1991).

Chiew and McMahon (1993, 1994) made a sensitivity analysis of the 17-parameter MODHYDROLOG model and showed that modeled streamflows were insensitive to many of the parameters. Eventually, the simplified 7-parameter SIMHYD model was developed.

The original AWBM model (Boughton 1993) had 7 parameters. Boughton (2004) showed that a fixed pattern of the surface storages and their partial areas would give results that were close to the results from calibration of all 7 parameters. This reduced the five surface storage parameters to one and the total number of parameters to three - one for the surface storage pattern, one to determine baseflow recharge, and one to determine baseflow discharge. Cheung and Yu (1999) made a separate study to show that the 3 surface stores could be reduced to 2 without significant loss of accuracy in simulating monthly totals of runoff, but they did not test for loss of accuracy on daily flows or on catchments in drier areas with marginal runoff.

There have been other sensitivity studies on Australian models that are omitted for sake of brevity. The studies mentioned above show that there have been many efforts over the last two decades to simplify models. A major objective of most of the studies has been to relate the reduced number to catchment characteristics for use on ungauged catchments. This objective has not yet been achieved. 


\section{Water Balance Modelling For Flood Estimation}

The main application of water balance modelling in Australia has been calculation of water yield at daily time steps. There has always been interest in the use of water balance modelling for estimation of losses in design flood estimation but such applications has been very few compared with the application to water yield. Australian Rainfall and Runoff is the main design flood estimation manual produced by the Institution of Engineer, Australia. When the $3^{\text {rd }}$ edition was prepared in 1987, the description of continuous simulation water balance models for use in flood estimation was confined to a small section at the end of the chapter on Runoff Routing Methods.

The Monash model, developed by Porter (1972), can be used with either an hourly time step for flood estimation or daily time step for water yield. The daily version has always been the main version used in practice and there is no record of any significant use of the hourly version for design flood estimation.

Interest in computer simulation for design flood estimation increased significantly in 1997 when the Cooperative Research Centre for Catchment Hydrology began the FL 1.2 sub-project "Holistic approach to rainfall-based design flood estimation: continuous simulation approach". The outcome of this project was the Continuous Simulation System for Design Flood Estimation (Boughton 1999, Boughton et al 1999, 2000). The system uses the AWBM water balance model to calculate rainfall excess at hourly time steps during storms and daily time steps between storms. A flood hydrograph model (WBMOD) converts the hourly rainfall excess to hourly streamflow at the catchment outlet. Droop and Boughton modified the system by replacing WBMOD with the WBNM runoff routing model, and then with RORB (Droop and Boughton 2003). Both RORB and WBNM are flood hydrograph models in widespread use in Australia.

The review by Boughton and Droop (2003) covers the use of continuous simulation for design flood estimation in Australia, USA, UK-Europe and South Africa. The coverage of the different countries provides a contrast of Australian work with that undertaken overseas.

Flood forecasting has many similarities with design flood estimation in the models and methods used; however, the use of water balance modelling in flood forecasting in Australia is virtually zero.

\section{Ungauged Catchments}

While computer simulation of catchment water balance was still in an early phase of development, the Australian Water Resources Council (1971) made a study of the USDA Curve Number Method to test its ability for estimating runoff from ungauged catchments. The method was the original manual calculation, event-based version and not the later moisture accounting version. Boughton (1989) reviewed the results. The test results were not of sufficient accuracy to encourage further testing or development.

Another part of the AWRC study of the hydrology of small rural catchments was the testing of the Boughton model for possible use on ungauged catchments (Snowy Mountains Engineering Corporation, 1971). Johnston and Pilgrim (1976) attempted to derive optimum values for the model parameters with an objective of relating the optimum values to measurable catchment characteristics. This study showed very clearly the problem of interrelationships among model parameters and the low sensitivity of some objective functions to a wide range of combinations of 
parameter values. Mein and Brown (1978) tested the sensitivity of each parameter in a modified version of the model to assess the potential for predicting the effects of land use change on runoff. They reported that, while the model performed well in relating runoff to rainfall in a calibration situation, the parameters could not be related to catchment characteristics with sufficient confidence to assess the effects of land use change.

When the Boughton model was simplified to the SFB model, the latter was used in a major study directed towards its use on ungauged catchments. First, Nathan and McMahon (1990a) verified that the simplification of the model gave good results in a calibration situation and that the simplification could not be improved. They then calibrated the model on 168 catchments in New South Wales and Victoria (Nathan and McMahon 1990b). They were unable to find any useful correlations between the calibrated parameters values and measurable characteristics of the catchments. This study was funded by the Australian Water Research Advisory Council (Project 85/105).

Nathan et al (1996) tested the 2-parameter MOSAZ model on 195 catchments in Victoria in a study funded by the Water Resources Management Branch of the Department of Conservation and Natural Resources, Victoria. They developed regression equations for the two parameters, but reported: "The lack of physical basis of the equations means that considerable caution should be exercised if attempting to predict model parameters in catchments that lie outside the geographic and physical limits used in their derivation”.

The conclusions of this study stated " The history of research into the development of process models for application to ungauged catchments has continued uninterrupted for almost 30 years. Unfortunately, it is likely that the pursuit of this challenge will continue to frustrate researchers for many years to come.”

Boughton and Chiew (2003) calibrated a version of the AWBM (UGAWBM) on data from 221 catchments located over a wide range of mainland Australia. This version is a 3-parameter model specifically developed for estimating runoff from ungauged catchments. The data sets were from the same group used with the SIMHYD model for the National Land and Water Audit. In this case, the calibrations have been presented for use by others because of the wide coverage of the data instead of attempting to relate parameters to catchment characteristics. This report was only made available a few months before the present writing, so it is too early to assess if this study will make any impact on the ungauged catchment problem.

While most of the studies have been made with simple models with few parameters, Weeks and Ashkanasy (1985) attempted to relate parameters of the Sacramento model to catchment characteristics in a group of 8 sub-catchments, 88 to $880 \mathrm{~km}^{2}$ in area, in the Lockyer Valley in south east Queensland. Even though the group of sub-catchments were contiguous in a localized area, the results were so variable that there was no further follow-on work.

The problem of ungauged catchments is not unique to Australia. In 2002, the International Association of Hydrological Sciences (IAHS) initiated the Decade for Prediction in Ungauged Basins (PUB). Australia is actively participating in this program (Sivapalan 2003).

\section{Current Situation And Possible Future Trends}

\subsection{Range of applications}


At the beginning of computer simulation of catchment water balance, the main purpose was the estimation of runoff for water yield studies, and calculated monthly totals of runoff were the main interest. The calculations for monthly totals were made at daily time steps; hence daily runoff values soon became a purpose of calculation. The interest in calculation of daily flows has steadily increased up to the present.

The use of sub-daily water balance modelling for flood studies began in the late 1960s, but was a relatively minor application until the late 1990s. The main turning point was the FL 1.2 research programme of the Cooperative Research Centre for Catchment Hydrology. At the time of writing, interest in the Continuous Simulation System for Design Flood Estimation that resulted from the FL 1.2 programme is increasing rapidly.

The third major application is modelling of large catchments for water resources allocation and management. In the 1970s and 1980s, the trend was for development of an individual daily water balance model for each catchment of interest. The several models developed for management of the River Murray (the largest river basin in Australia) were examples of catchment-specific models. The development of the IQQM system (see Section 3.5) was the first general purpose model that could be applied to many different catchments.

AQUACYCLE illustrates a trend towards water balance models that are specifically developed for the needs of urban water management. Non-urban catchments dominated in the development of water balance models for most of the period covered in this report, and non-urban models were adapted for use on urban catchments as needs arose. The interest in urban catchments is now sufficient that development of water balance models for urban catchments is likely to continue as a defined part of overall development.

There is increasing interest in the water needs of aquatic ecosystems, often called in-stream needs to distinguish them from extractions from a stream for ex-stream uses. To date, the models developed for other purposes have been used for modelling flows for in-stream needs and no specific models for that purpose have been developed. There are similar needs in the transport of sediment, salt and nutrients in runoff where models developed for other purposes are used, and no water balance models specifically directed to the transport issues are yet in common use.

The final application to mention is the conversion of the estimates of climate change to estimates of change in streamflow. At the time of writing, the global models used to estimate future changes in rainfall and evaporation have an accuracy that is several orders of magnitude worse than the water balance models currently available for converting those estimates to estimates of change in streamflow. The currently available water balance models are likely to be more than adequate for this purpose for at least several decades into the future.

\subsection{Model Developments as Higher Degree Projects}

Many of the water balance models developed in Australia have been the products of higher degree projects in universities. The projects are usually low cost with little needed beyond the use of a personal computer. There are no delays due to weather or lack of equipment. The rainfall, evaporation and streamflow data are usually readily available. These conditions are ideal for higher degree projects. 
Models have reached the stage of performance that future projects need to be directed to more specific purposes than development of more models. The lack of achievement on the ungauged catchment problem leaves that opportunity open under similar conditions as in the past. The need for models that join rainfall-runoff models with models for transport of sediment, salt and nutrients is likely to continue, but the opportunities for progress with joint runoff-transport models in higher degree projects will be limited by the availability of data sets for analysis.

At present, research funding for universities in Australia is subject to "outcome orientation" performance measurement. There is much to be gained by demonstrating that much of the substantial benefits that have been obtained in water resources management in Australia by improved ability to model the water balance of catchments has been gained at little cost from a small number of higher degree programs. The benefits are evident in such applications as the use of SIMHYD for estimating long term sequences of streamflows for the National Land and Water Audit (Peel et al 2001, Chiew et al 2002a), and the modelling of runoff for the South East Queensland Environmental Management Support System (Chiew et al 2002b).

\subsection{Errors in Input Data}

It is a cliché among catchment modelers that most modern water balance models will give good results with good quality input data and poor results with poor quality input data. In other words, the quality of the results is more dependent on the quality of the input data than on the model chosen for use. The biggest problem is sampling errors when the selected input data are not representative of the entire catchment. The standard $203 \mathrm{~mm}$ (8-inch) rain gauge has a catch area of $1 / 3,000,000 \mathrm{sq} . \mathrm{km}$. and the rain gauge network in Australia is one gauge to about 10 to $100 \mathrm{~km}^{2}$. Rainfall has much more spatial and temporal variability than evaporation, and it is the sampling errors of the spatial variability of rainfall that is the biggest problem with catchment scale water balance modelling. The following evidence is presented to show that the poor quality of input data for water balance modelling is a serious problem.

Nathan and McMahon (1990a, b) calibrated the SFB model on 168 catchments, 1 to $250 \mathrm{~km}^{2}$ in area, in southeastern mainland Australia to study of the potential of the model for use on ungauged catchments. Rainfall data for the study were provided by the Bureau of Meteorology, and runoff data by the main streamflow measuring authorities in New South Wales and Victoria. The model was found to be satisfactory in these words: "Overall, it is concluded that the SFB model is robust and simple to use, and given good input data, it is generally possible to achieve an acceptable calibration”. The data were commented on in these words: “... calibration results with (a coefficient of determination) less than 0.6 or (overall difference between observed and simulated flow volumes) greater than $\pm 10 \%$ are generally too poor to be considered acceptable and are of little practical benefit; approximately $37 \%$ of the calibrations undertaken fall into this category. These poor calibration results were generally associated with catchments in which the water balance problems infer that the rainfall and evaporation data were not representative of catchment conditions".

The quality of more than one-third of data in this study was too poor to be useable. This is not a criticism of the authorities providing the data. It serves to demonstrate how difficult it is to get input data of sufficient quality to be able to model the water balance of catchment areas. This difficulty is not widely understood.

Boughton and Chiew (2003) calibrated the AWBM on rainfall and runoff data from 331 catchments, 50 to $2000 \mathrm{~km}^{2}$ in area, spread among the States and Territories of Australia. The data 
had earlier been collated for a project for the National Land and Water Resources Audit (Peel et al 2001, Chiew et al 2002a). The daily rainfall data were prepared by the Queensland Department of Natural Resources and Mining. The streamflow data were provided by the main gauging authority in each State and Territory. Boughton and Chiew reported that problems with the data resulted in the discarding of some data sets. The problems included:

- inconsistent data in which runoff exceeded rainfall for sufficient periods of time to indicate that either the rainfall or the runoff data had errors;

- data in which the rainfall showed evidence of systematic bias, i.e. that it was either too big or too small to be consistent with the runoff, resulting in calibrated parameter values that were out of physically plausible ranges;

- data with random errors between rainfall and runoff such that the resulting correlation between calculated and actual monthly runoff was sufficiently poor that there was no confidence in the calibration.

As a result of these problems, acceptable calibrations could only be made on 221 catchments; i.e. the input data were not satisfactory on $33 \%$ of the catchments.

The classification as 'unsatisfactory' of one-third of data sets in two major water balance modelling studies is evidence that the selection of input data for modelling (particularly rainfall data) is neither easy nor well enough understood to be treated as a routine task. Substantially more attention to the quality of rainfall input data will be needed before the technology of catchment water balance modelling makes further progress.

Evaporation has much less spatial and temporal variability than rainfall; hence the output from rainfall-runoff models is less sensitive to change or errors in evaporation than in rainfall. Chapman (2003) showed that average monthly evaporation can be used as a surrogate for daily evaporation without any significant loss of accuracy in the modelling of runoff. However, the sparse network of point measurements of pan evaporation and the need to extrapolate to large catchment areas provides an enormous area of uncertainty.

\subsection{Effects of Land Use on Runoff}

The problem of estimating runoff from ungauged catchments, discussed in Section 7, is closely related to the problem of estimating the change in runoff that will occur when the land use of a catchment changes. World-wide, most studies of change in land use have been directed towards the effect of change from forest to grass cover.

The catchments supplying water to the city of Melbourne are single purpose and closed to other uses, even recreational use. In the 1960s, pressure from those wanting to harvest some of the valuable timber resources in the catchment areas resulted in the establishment of a major research program to study the effects of timber harvesting on water yield (Langford et al, 1982). Several studies have used water balance models to study the hydrological effects of clear felling using data from the program (Jayasuriya and O’Shaughnessy, 1988, Post et al, 1996). The Macaque model (Watson et al 2001) has been used to assess the effect of forest clearing on catchment yield in Victorian and Tasmanian forests. A review of similar research programs in Australia up to 1970 is given by Boughton (1970).

It would be optimistic to believe that the effects of catchment characteristics and land use on runoff can be evaluated before the problems of quality of input data have been rectified. 
A missing component in current water balance models is transmission loss in stream channels between the areas where runoff is generated and the catchment outlet where runoff is measured. Transmission loss can occur in streams in all climates but it is most significant in drier regions where runoff is small. The ratio of transmission loss to total runoff increases as rainfall and runoff decrease. The importance of transmission loss is increasing as the importance of low flows for both water allocation and aquatic ecosystems increases.

Stewart and Boughton (1983) reviewed the available information on transmission losses. They reported a few measurements of losses in Australian streams but the majority of the data was from the USA. Droop and Boughton (2001) updated the review to the start of the new millennium.

There are no published reports of Australian water balance models incorporating transmission loss components, although the writer is aware of allowances for transmission loss in some water management models operated by State water authorities. The allowances seem to be catchment specific, based on experience in managing the resource, and not based on any general transmission loss model.

At present, the modelling of transmission loss is the least developed part of Australian water balance models. A notable exception is the modelling study by Costello et al (2003) in which transmission loss is incorporated into a distributed model for study of arid zone catchments in the Lake Eyre Basin - a large internal drainage basin in central Australia.

\subsection{Stochastic generation of rainfall data}

The full potential of a continuous simulation rainfall-runoff model is best achieved when it is combined with a stochastic rainfall generation model. The main purpose of rainfall-runoff modelling is to extend short records of streamflow by using the longer records of rainfall. While 50 to 100 years of rainfall data are available at many stations in Australia, stochastic generation of rainfall data in combination with a calibrated rainfall-runoff model allows the generation of as many thousands of years of streamflow data as needed for design purposes. A modern personal computer can generate thousands of years of daily rainfall data and then calculate the daily streamflows in a time measured in minutes, not hours.

Developments in water balance modelling have been matched by developments in stochastic rainfall generation in the last three decades. Currently, satisfactory stochastic models for generating both daily and hourly rainfalls are available at a single site. There is current research directed towards multi-site generation of rainfall to extend stochastic rainfall generation to larger areas with spatial variability of rainfall.

\subsection{Distributed modelling}

One of the biggest limitations of the rainfall-runoff models that are widely used in practice is their lack of representation of areal variability within the catchment. There are many distributed models available for use but little data available on which to realistically calibrate distributed parameter values. Some effort to overcome the problem is currently being pursued in Australia in research organizations such as the Cooperative Research Centre for Catchment Hydrology. The web site of 
this CRC at www.catchment.crc.org.au is a useful source of information. Grayson et al (1992a,b) used the Thales model to examine a range of issues to do with distributed modelling.

\section{Concluding Comments}

Several features of the Australian hydrological environment have had an effect on the development of water balance modelling. The sparsity of streamgauging stations over much of the continent made assessment of available water difficult, and resulted in an emphasis on water yield instead of flood estimation in modelling studies. The sparsity of pluviometer stations promoted a reliance on generalized intensity-frequency-duration rainfall statistics for event-based flood estimation that delayed interest in continuous simulation water balance modelling for flood estimation until the last decade.

Catchment hydrology has been dominated by the needs of engineering design, not pure research. This is evident in two areas. Almost all of the developments in water balance modelling have been made by engineers, and these have occurred mainly in higher degree projects in engineering schools in universities. The other area is the trend to development of simple water balance models compared with more complex models developed elsewhere. Several studies of parameter sensitivity have resulted in the simplification of models by reduction in the number of variable parameters. The motivation behind this trend is the need in engineering practice to be able to estimate runoff from ungauged catchments. This need remains unfulfilled.

For a small country with a population of only 20 million people, Australia has produced a disproportional large amount of catchment hydrology research. This has been a result of necessity because of the small and highly variable streamflows over much of the continent. This paper gives a perspective of an important part of that research at a time when it is still possible to record the origins and developments that have led to that perspective.

\section{Acknowledgements}

I am grateful to Professor R. Mein, Professor T. McMahon, Professor T. Chapman and Dr. K. Renard who gave comments on an early draft and helped by drawing my attention to additional studies. However, all of the comments and opinions expressed in the paper are those of the author.

\section{References}

Australian Water Resources Council, 1969. The representative basins programme concept in Australia. Hydrological Series no.2, AGPS, Canberra.

Australian Water Resources Council, 1971. Research Report 68/1 Hydrology of small rural catchments. Final report vol.2 - Report on analysis components. Prepared by Snowy Mountains Engineering Corp., Cooma, New South Wales.

Australian Water Resources Council, 1973. Australian representative basins programme - progress 1973. Hydrological Series no.8, AGPS, Canberra.

Ayers, H. D., 1962. A survey of watershed yield. Univ. of New South Wales, Water Res. Lab. Report no.63. 
Bell, F. C., 1966. A survey of recent developments in rainfall-runoff estimation. Jour. Institution of Engineers, Australia, 38(3), 37-47.

Black, D. C. and Aitken, A. P., 1977. Simulation of the urban runoff process. Australian Water Resources Council, Tech. Paper no.26, AGPS, Canberra.

Boughton, W. C., 1964. A new simulation technique for estimating catchment yield. M.E. Thesis, Univ. of New South Wales, Sydney.

Boughton, W. C., 1968. A mathematical model for estimating runoff. Jour. of Hydrology, New Zealand, 7(2), 75-100.

Boughton, W. C., 1970. Effects of land management on quantity and quality of available water: a review. Water Research Lab. Report 120, University of New South Wales, Sydney.

Boughton, W. C., 1984. A simple model for estimating the water yield of ungauged catchments. Civil Engg. Trans., Institution of Engineers, Australia, CE26(2), 83-88.

Boughton, W. C., 1988. Modelling the rainfall-runoff process at the catchment scale. Civil Engg. Trans., Institution of Engineers, Australia, CE30(4), 153-162.

Boughton, W. C., 1989. A review of the USDA SCS curve number method. Australian Jour. of Soil Research, 27, 511-523.

Boughton, W. C., 1993. A hydrograph-based model for estimating the water yield of ungauged catchments. In: Proceedings of the 1993 Hydrology and Water Resources Symposium, Institution of Engineers, Australia, National Conference Publication 93/14, 317-324.

Boughton, W. C., 1999. A continuous simulation system for design flood estimation - operating manual. Unpublished report, available as a computer file with system software on www.catchment.crc.org.au/models

Boughton, W. C., 2004. The Australian Water Balance Model. Environmental Modelling \& Software, accepted for publication, in press May 2004.

Boughton, W. C. and Carroll, D. G., 1993. A simple combined water balance/flood hydrograph model. In: Proceedings of the 1993 Hydrology and Water Resources Symposium, Institution of Engineers, Australia, National Conference Publication 93/14, 299-304.

Boughton, W. C. and Chiew, F., 2003. Calibrations of the AWBM for use on ungauged catchments. Tech. Report 03/15, CRC for Catchment Hydrology, Monash University, 37 pp.

Boughton, W. C. and Droop, O., 2003. Continuous simulation for design flood estimation - a review. Environmental Modelling \& Software, 18(4), 309-318.

Boughton, W. C., Muncaster, S. H., Srikanthan, R., Weinmann, P. E. and Mein, R. G., 1999. Continuous simulation for design flood estimation - a workable approach. In: Proceedings WATER99 Joint Congress, Brisbane, Institution of Engineers, Australia, 1, 178-183. 
Boughton, W., Srikanthan, S. and Weinmann, E., 2000. Benchmarking a new design flood system. In: Proceedings Hydro2000 Hydrology and Water Resources Symposium, Perth, Institution of Engineers, Australia, 570-575.

Burnash, R. J., 1975. Chapter 10. The NWS river forecast system - catchment modelling. In Singh, V. P. (ed.) 'Computer models of watershed hydrology', Water Resources Publications, Littleton, Colo.

Burnash, R. J., Ferral, R. L. and McGuire, R. A., 1973. A generalized streamflow simulation system - conceptual modelling for digital computers. U.S. Dept. of Commerce, National Weather Service, Silver Springs, Md. and State of California, Dept. of Water Resources, Sacramento, Calif.

Chapman, T. G., 1968. Catchment parameters in a deterministic rainfall-runoff model. In: Stewart, G. A. (ed.) “Land Evaluation”, Macmillan, Melbourne.

Chapman, T. G., 2003. Estimation of evaporation in rainfall-runoff models. Proceedings MODSIM 2003 International Congress on Modelling and Simulation, Modelling and Simulation Society of Australia, 1, 148-153.

Chapman, T. G. and Dunin, F. X. (eds.), 1975. Prediction in catchment hydrology. Australian Academy of Science, Canberra.

Cheung, L and Yu, B., 1999. Three conceptual stores in AWBM. Are they really necessary? In: Proceedings of the Water99 Joint Congress, Institution of Engineers, Australia, vol. 2, pp. 993-998

Chiew, F. H., 1990. Estimating groundwater recharge using an integrated surface and groundwater model. PhD thesis, Dept. of Civil and Agricultural Engg., Univ. of Melbourne, 357 pp.

Chiew, F. H. and McMahon, T. A., 1990. Estimating groundwater recharge using a surface watershed modelling approach. Jour. Hydrology, 114, 285-304.

Chiew, F. H. and McMahon, T. A., 1991. Improved modelling of the groundwater processes in HYDROLOG. Intern. Hydrology \& Water Resources Conference, Institution of Engineers, Australia Nat. Conf. Publ. no. 91/22, vol.2, 492-497.

Chiew, F. H. and McMahon, T. A., 1993. Data and rainfall-runoff modelling in Australia. Hydrology \& Water Resources Symposium, Institution of Engineers, Australia, Nat. Conf. Publ. 93/14, 305-316.

Chiew, F. H. and McMahon, T. A., 1994. Application of the daily rainfall-runoff model MODHYDROLOG to 28 Australian catchments. Jour. Hydrology, 153, 383-416.

Chiew, F. H., Peel, M. C. and Western, A. W., 2002a. Application and testing of the simple rainfallrunoff model SIMHYD. In V. P. Singh and D. K. Frevert (eds.) 'Mathematical models of small watershed hydrology and applications’, Water Resources Publications, Littleton, Colo., 335-367.

Chiew, F., Scanlon, P., Vertessy, R. and Watson, F., 2002b. Catchment scale modelling of runoff, sediment and nutrient loads for SouthEast Queensland EMSS. CRC for Catchment Hydrology, Monash Univ., Melbourne, Tech. Rept. 02/01, 50 pp. 
Costello, J. F., Grayson, R. B., Argent, R. M. and McMahon, T. A., 2003. Modelling the flow regime of an arid zone floodplain river, Diamantina River, Australia. Environmental Modelling \& Software, 18, 693-703.

Croke, B. F. and Jakeman, A. J., 2001. Predictions in catchment hydrology: an Australian perspective. Marine Freshwater Research, 52, 65-79.

Croke, B. F. and Jakeman, A. J., 2004. A catchment moisture deficit module for the IHACRES rainfall-runoff model. Environmental Modelling and Software, 19, 1-5.

Droop, O. and Boughton, W., 2001. Transmission losses. Research Report 2/01, Gilbert \& Associates, Brisbane, 10 pp.

Droop, O. and Boughton, W., 2003. Integration of RORB into a continuous simulation system for design flood estimation. In: Proceedings $28^{\text {th }}$ Intern. Hydrology \& Water Resources Symposium, Wollongong, Institution of Engineers, Australia, 1, 113-120.

Evans, J. P. and Jakeman, A. J., 1998. Development of a simple, catchment-scale, rainfallevapotranspiration-runoff model. Environmental Modelling and Software, 13, 385-393.

Fleming, G., 1975. Computer simulation techniques in hydrology. Elsevier.

Fleming, P. M., 1971. The Australian representative basins programme and its hydrological model. Institution of Engineers, Australia Hydrology Papers 1971, 86-95.

Goyen, A. G., Phillips, B. C. and Black, D. C., 1991. Recent advances in flood estimation using RAFTS-XP. In: Proceedings of the Intern. Hydrology \& Water Resources Symposium, Institution of Engineers, Australia, 1, 66-71.

Grayson, R. B., Moore, I. D. and McMahon, T. A., 1992a. Physically based hydrologic modelling. I: A terrain-based model for investigative purposes. Water Resources Research, 28(10), 2639-2658.

Grayson, R. B., Moore, I. D. and McMahon, T. A., 1992b. Physically based hydrologic modelling. II: Is the concept realistic? Water Resources Research, 28(10), 2659-2666.

Haan, C. T., Johnson, H. P. and Brakensiek, D. L. (eds.), 1982. Hydrologic modelling of small watersheds. Monograph \#8, ASAE St Joseph, Michigan.

Jakeman, A. J., Littlewood, I. G. and Whitehead, P. G., 1990. Computation of the instantaneous unit hydrograph and identifiable component flows with application to two small upland catchments. Jour. Hydrology 117, 275-300.

Jayasuriya, L. N., 1991. A methodology for estimating yield from small ungauged rural catchments. $\mathrm{PhD}$ thesis, University of Melbourne.

Jayasuriya, L. N., McMahon, T. A. and O’Neill, I. C., 1991. Development of a simplified twoparameter rainfall-runoff model with potential for ungauged catchment application. Intern. Hydrology \& Water Resources Symposium, Perth, Institution of Engineers, Australia, 2, 498-503. 
Jayasuriya, L. N. and O’Shaughnessy, P. J., 1988. The use of mathematical models in evaluating forest treatment effects on streamflow. Proceedings Hydrology and Water Resources Symposium, Institution of Engineers, Australia, National Conference Publication 88/1, 135-139.

Johnston, P. R. and Pilgrim, D. H., 1976. Parameter optimization for watershed models. Water Resources Research, 12(3), 477-486.

Langford, K. J., Moran, R. J. and O’Shaughnessy, P. J., 1982. The Coranderrk experiment: the effects of roading and timber harvesting in a mature mountain ash forest on streamflow yield and quality. In: E. M. O’Loughlin and L. J. Bren (Editors), The First National Symposium on Forest Hydrology, Institution of Engineers, Australia, National Conference Publication 82/6, 92-102.

Littleboy, M., Silburn, D. M., Freebairn, D. M., Woodruff, D. R. and Hammer, G. L., 1993. PERFECT A computer simulation model of Productivity Erosion Runoff Functions to Evaluate Conservation Techniques. Queensland. Dept. of Primary Industries, Training Series QE93010, 119 pp.

Marston, F., Argent, R., Vertessy, R., Cuddy, S. and Rahman, J., 2002. The status of catchment modelling in Australia. Cooperative Research Centre for Catchment Hydrology, Monash Univ., Melbourne, Tech. Rept. 02/04.

Mein, R. G., 1977. Mathematical modelling of catchments. Institution of Engineers, Australia Hydrology Symposium, Brisbane, 146-150.

Mein, R. G. and Brown, B. M., 1978. Sensitivity of optimised parameters in watershed models. Water Resources Research, 14(2), 299-303.

Mitchell, V. G., Diaper, C., Gray, S. R. and Rahilly, M., 2003. UVQ: Modelling the movement of water and contaminants through the total urban water cycle. In: Proceedings $28^{\text {th }}$ Hydrology \& Water Resources Symposium, Wollongong, Institution of Engineers, Australia, 3, 131-138.

Mitchell, V. G., Mein, R. G. and McMahon, T. A., 1997. Evaluating the resource potential of stormwater and wastewater; an Australian perspective. Aust. Jour. Water Resources, 2(1), 19-22.

Mockus, V., 1949. Estimation of total (and peak rates of) surface runoff for individual storms. In “Interim Survey Report Grand (Neosho) River Watershed”, Exhibit A of Appendix B, US Dept. of Agriculture.

Nathan, R. J., Austin, K., Crawford, D. and Jayasuriya, N., 1996. The estimation of monthly yield in ungauged catchments using a lumped conceptual model. Aust. Jour. of Water Resources, 1(20), 65-75.

Nathan, R. J. and McMahon, T. A., 1990a. The SFB model part I - validation of fixed model parameters. Civil Engg. Trans., Institution of Engineers, Australia, CE32(3), 157-161.

Nathan, R. J. and McMahon, T. A., 1990b. The SFB model part II - operational considerations. Civil Engg. Trans., Institution of Engineers, Australia, CE32(3), 162-166. 
Nathan, R. J. and McMahon, T. A., 1990c. The estimation of low flow characteristics and yield from small ungauged rural catchments. AWRAC Research Project Report 85/105, Dept. of Primary Industries and Energy, Canberra, 213 pp.

Ogrosky, H. O. and Mockus, V., 1964. Hydrology of agricultural lands. In: V. T. Chow (ed.) 'Handbook of Applied Hydrology', Sect. 21, McGraw Hill, New York.

O'Loughlin, E. M., 1986. Prediction of surface saturation zones in natural catchments by topographic analysis. Water Resources Research, 22(5), 794-804.

O’Loughlin, E. M., Short, D. L. and Dawes, W. R., 1989. Modelling the hydrologic response of catchments to land use change. Hydrology and Water Resources Symposium, Christchurch, NZ, Institution of Engineers, Australia, National Conference Publication no. 89/19, 335-340.

Pattison, A. and McMahon, T. A., 1973. Rainfall-runoff models using digital computers. Civil Engg. Trans., Institution of Engineers, Australia, CE15(1-2), 1-4 \& 20.

Peel, M. C., Chiew, F. H., Western, A. W. and McMahon, T. A., 2001. Extension of unimpaired monthly streamflow data and regionalisation of parameter values to estimate streamflow in ungauged catchments. Report prepared for the National Land and Water Resources Audit. in http://audit.ea.gov.au/anra/water/docs/national/streamflow/streamflow.pdf

Phillips, B. C. and Boon, B., 1999. Estimating peak flood flows in the Welcome River catchment, northwest Tasmania. In: Proceedings of the WATER99 Joint Congress, Institution of Engineers, Australia, 2, 913-918.

Ponce, V. M. and Hawkins, R. H., 1996. Runoff curve number: has it reached maturity. ASCE Jour. Hydrologic Engg., 1(1), 11-19.

Porter, J. W., 1972. The synthesis of continuous streamflow from climatic data by modelling with a digital computer. PhD thesis, Monash Univ.

Porter, J. W. and McMahon, T. A., 1971. A model for simulation of streamflow data from climatic records. Jour. Hydrology, 13, 297-324.

Porter, J. W. and McMahon, T. A., 1976. The Monash model: User manual for daily program HYDROLOG. Dept of Civil Engg., Monash Univ., Research Rept. no.2/76, 41 pp.

Post, D. A., Jakeman, A. J., Littlewood, I.G., Whitehead, P. G. and Jayasuriya, M.D., 1996. Modelling land-cover-induced variations in hydrologic response: Picaninny Creek, Victoria. Ecological Modelling, 86, 177-182.

Rallison, R. E., 1980. Origin and evolution of the SCS runoff equation. In: Symposium of Watershed Management 1980, vol. II, ASCE, New York, 912-924.

Silberstein, R. P., Vertessy, R. A., Morris, J. and Feikema, P. M., 1999. Modelling the effects of soil moisture and solute conditions on long-term tree growth and water use: a case study from the Shepparton irrigation area, Australia. Agricultural Water Management, 39, 283-315. 
Simons, M., Podger, G. and Cooke, R., 1996. IQQM - A hydrologic modelling tool for water resource and salinity management. Environmental Software, 11(1-3), 185-192.

Singh, V. P., 1995. Computer models of watershed hydrology. Water Resources Publications, Littleton, Colo.

Singh, V. P. and Frevert, D. K. (eds.), 2002. Mathematical models of small watershed hydrology and applications. Water Resources Publications, Littleton, Colo., 335-367.

Singh, V. P. and Woolhiser, D. A., 2002. Mathematical modelling of watershed hydrology. ASCE Jour. of Hydrologic Engineering, 7(4), 270-292.

Sivapalan, M., 2003. Prediction in ungauged basins: a grand challenge for theoretical hydrology. Hydrological Processes, 17: 3163-3170.

Snowy Mountains Engineering Corporation, 1971. Hydrology of small rural catchments. Aust. Water Resources Council Research Project 68/1, SMEC, Cooma, New South Wales.

Stewart, B. J. and Boughton, W. C., 1983. Transmission losses in natural streambeds - a review. In: Proceedings Hydrology and Water Resources Symposium, Hobart, Institution of Engineers, Australia, National Conference Publication 83/13, 226-230.

Sukvanachaikul, Y. and Laurenson, E. M., 1983. An improved rainfall-runoff model for semi-arid regions. Hydrology \& Water Resources Symposium, Hobart, Institution of Engineers, Australia Nat. Conf. Publ. 83/13, pp.108-112.

Todini, E., 1988. Rainfall-runoff modelling: past, present and future. Jour. Hydrology, 100, 341352.

Watson, F., Vertessy, R., McMahon, T., Rhodes, B. and Watson, I., 2001. Improved methods to assess water yield changes from paired-catchment studies: application to the Maroondah catchments. Forest Ecology and Management, 143(1-3), 189-204.

Weeks, W. D. and Ashkanasy, N. M., 1985. Regional parameters for the Sacramento model: a case study. Civil Engg. Trans., Institution of Engineers, Australia, CE27(3), 305-313.

Wheater, H. S., Jakeman, A. J. and Beven, K. J., 1993. Progress and directions in rainfall-runoff modelling. In: Jakeman, A. J., Beck, M. B. and McAleer, M. J. (eds.), "Modelling Change in Environmental Systems”, John Wiley \& Sons Ltd.

Williams, J. R. and LaSeur, W. V., 1976. Water yield model using SCS curve numbers. ASCE Jour. Hydraulics Division, 102, 1241-1253.

World Meteorological Organization (WMO), 1975. Intercomparison of conceptual models used in operational hydrological forecasting. Operational Hydrology Paper no. 429, Geneva. 

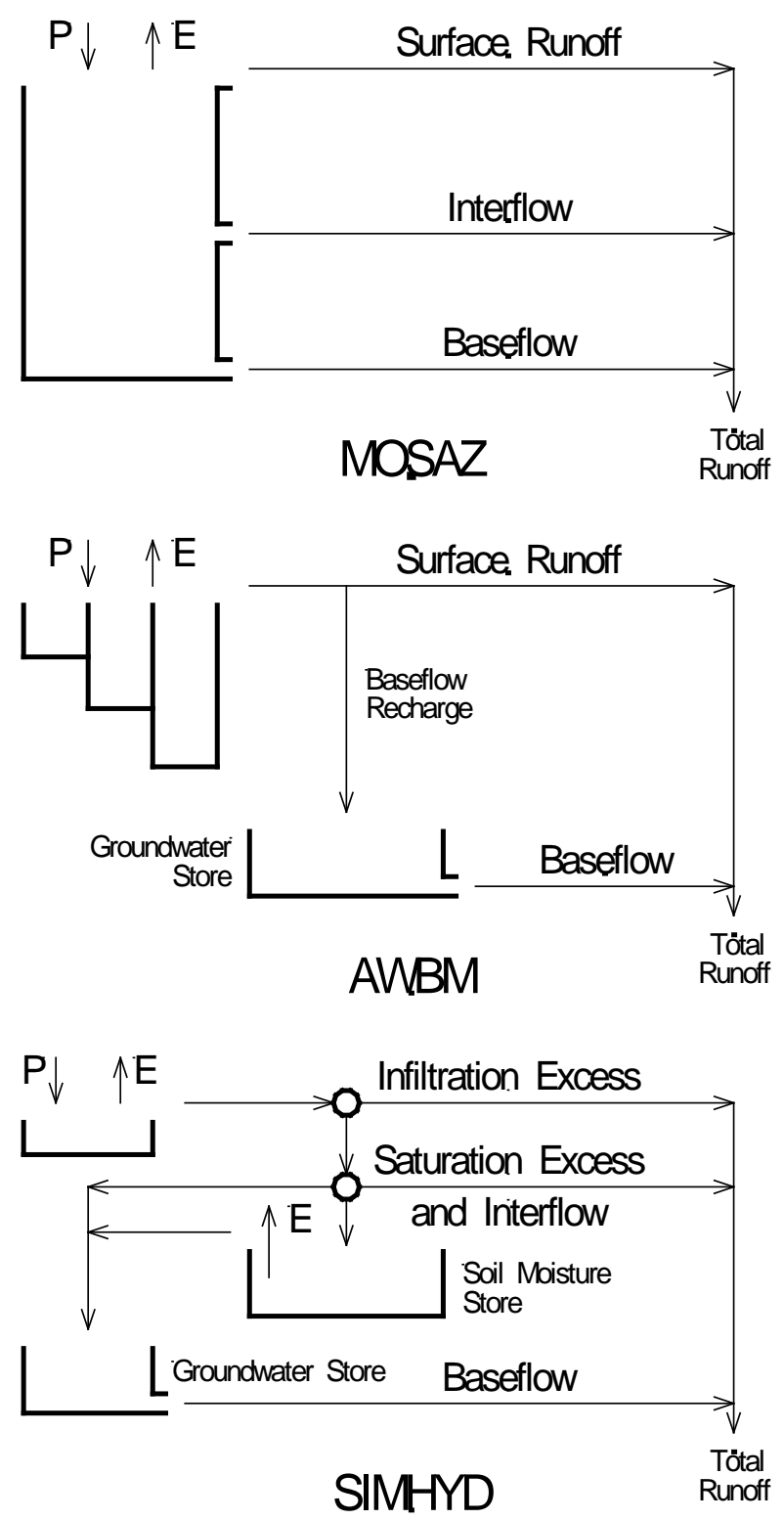

Fig. 1. Structure of three Australian water balance rainfall-runoff models 
Table 1

Some Australian catchment water balance models

\begin{tabular}{|c|c|c|}
\hline Model Name & Explanation of Name & Reference \\
\hline Boughton & Name of developer & Boughton (1964) \\
\hline ARBM & Australian Representative Basins Model & Chapman (1968) \\
\hline Monash & Developed at Monash University & Porter (1972) \\
\hline SFB & Names of 3 parameters & Boughton (1984) \\
\hline Sacramento & First use on Sacramento River & Burnash et al (1973) \\
\hline MODHYDROLOG & Modification of HYDROLOG & Chiew (1990) \\
\hline SIMHYD & Simplification of HYDROLOG & Chiew \& McMahon (1993) \\
\hline TOPOG & Topographic analysis & O’Loughlin (1986) \\
\hline IHACRES & Inst. of Hydrology \& CRES & Jakeman et al (1990) \\
\hline AWBM & Australian Water Balance Model & Boughton (2004) \\
\hline MOSAZ & Modified Semi Arid Zone & Jayasuriya (1991) \\
\hline PERFECT & $\begin{array}{c}\text { Productivity Erosion Runoff Functions } \\
\text { to Evaluate Conservation Techniques }\end{array}$ & Littleboy e al (1993) \\
\hline AQUACYCLE & Water cycle in urban areas & Mitchell et al (1997) \\
\hline
\end{tabular}

